Tropical Journal of Pharmaceutical Research December 2015; 14 (12): 2247-2254

ISSN: $1596-5996$ (print); 1596-9827 (electronic)

(c) Pharmacotherapy Group, Faculty of Pharmacy, University of Benin, Benin City, 300001 Nigeria.

All rights reserved.

Available online at http://www.tjpr.org

Original Research Article

http://dx.doi.org/10.4314/tjpr.v14i12.14

\title{
Physicochemical, Nutritional, and Functional Characteristics of Seeds, Peel and Pulp of Grewia tenax (Forssk) Fiori Fruits
}

\author{
ElmuezAlsir A Aboagarib ${ }^{1-3}$, Ruijin Yang $^{1 *}$ and Xia Hua ${ }^{4}$ \\ ${ }^{1}$ State Key Laboratory of Food Science and Technology, Jiangnan University, Wuxi 214122, PR China, ${ }^{2}$ Department of Food \\ Science and Technology, Faculty of Engineering and Technology, University of Gezira, PO Box 20, ${ }^{3}$ Ministryof Health Gezira \\ Hospital for Renal Disease and Surgery, Wad Medani, Sudan, ${ }^{4}$ School of Food Science and Technology, Jiangnan University, \\ Wuxi 214122, PR China
}

*For correspondence: Email: yrj@jiangnan.edu.cn; Tel: +86-510-85919150; Fax: +86510-85919150

Received: 3 August 2015

Revised accepted: 8 November 2015

\begin{abstract}
Purpose: To determine the physicochemical, nutritional, and functional characteristics of the seeds, peel, and pulp of Grewia tenax (Forssk.) Fiori fruits.

Methods: The whole fruit was flooded with ionized water for $6 h$, and the seeds manually separated from the peel and pulp. The mineral content was determined by atomic absorption spectroscopy while the amino acids were separated and quantified by injecting $50 \mu \mathrm{L}$ into an amino acid analyzer (Hitachi 835-50). Gas chromatography-mass spectrometry (GC/MS) was used to separate and determine the volatile compounds, whereas color was measured with a digital colorimeter.

Results: Protein, fat and ash contents were higher in the seeds than in the peel and pulp. Carbohydrate content was higher in the pulp (87.09\%) than in the seeds and peel (59.56 and $70.74 \%)$, respectively. The peel, seeds, and pulp had $\mathrm{Na}$ concentration of $19.3,5.8$ and $11.5 \mathrm{mg} / 100 \mathrm{~g}$, respectively; and for potassium (K), 502.5, 400 and $300 \mathrm{mg} / 100 \mathrm{~g}$, respectively. The pulp contained the following essential amino acids: histidine, thereonine, valine, isoleucine and lysine at levels of 4.3, 6.4, 9.7, 9.5, and 6.4 $\mathrm{g} / 100 \mathrm{~g}$, respectively. The pulp had the highest water absorption capacity (WAC, $3.3 \mathrm{ml} / \mathrm{g}$ ), whereas oil absorption capacity was $3.6 \mathrm{ml} / \mathrm{g}$ in the peel. Foaming capacity (FC) was $8.6 \%$ in the seed. The bulk density $(B D)$ of seeds, peel, and pulp were $0.5,0.6$, and $0.9 \mathrm{~g} / \mathrm{mL}$, respectively. The concentration of the volatile components of seeds, peel, and pulp of the fruits was $42.1,97.9$, and $71.4 \%$, respectively.

Conclusion: Grewia tenax fruits are a good source of nutritional components and essential nutrients, including minerals and amino acids, and have functional properties, which, if properly utilized, can improve human nutrition and health.
\end{abstract}

Keywords: Grewia tenax, Physicochemical, Amino acids, Nutrition, Functional properties, Minerals, Volatile compounds

Tropical Journal of Pharmaceutical Research is indexed by Science Citation Index (SciSearch), Scopus, International Pharmaceutical Abstract, Chemical Abstracts, Embase, Index Copernicus, EBSCO, African Index Medicus, JournalSeek, Journal Citation Reports/Science Edition, Directory of Open Access Journals (DOAJ), African Journal Online, Bioline International, Open-J-Gate and Pharmacy Abstracts

\section{INTRODUCTION}

Grewia tenax (Forssk.) Fiori is a small-leaved white cross berry that belongs to the Tiliacea family. This fruit-producing deciduous shrub or small tree is prevalent in African and Southeast Asian countries, with the fruits known locally as guddaim in Sudan. The tree has a wide distribution in the savannah plantation area in the north and middle of Sudan [1]. Grewia tenax has been used in folk medicine in several ways in different countries. The roots have been used to treat jaundice, lungwort infections, and asthma. There is commercial potential in using the fruits 
in beverages, yogurt, ice cream, and baby food. The fruits are used by rural villagers as an iron supplement for anemic children. A thin porridge called nesha is prepared by boiling millet flour and the pulp of Grewia tenax fruits and then adding custard to the mixture [2]. This porridge is given to pregnant and lactating women to improve their health and their ability to produce milk for their children [3].

Some studies have shown that Grewia tenax fruits have been used as a traditional treatment for irritations and skin infections in both human beings and animals in Sudan. Grewia tenax fruits, which can be eaten ripe or stored for later use, consist of large quantities of carbohydrates in a liquefied form as well as a large quantity of calcium. Different parts of several species in the genus Grewia are used as folk medicine in various areas of the world.

The main objective of this study was to determine the nutritional value, amino acid content, color, levels of micronutrients and minerals, and functional properties (e.g., water and oil absorption capacities (WAC and OAC, respectively), bulk density (BD), foaming capacity (FC), and foam stability) of the different parts of Grewia tenax fruits.

\section{EXPERIMENTAL}

\section{Plant material}

Grewia tenax fruit was collected in September 2014 from a local market in Wad Medani City, Gezira State, Sudan and then placed in plastic bags and brought to Jiangnan University, Wuxi city, People's Republic of China. The samples were sorted to remove low-quality fruits and then stored in plastic bags at room temperature until use.

\section{Sample preparation}

The fruits were first washed with distilled water in a large bowl to eliminate any impurities or dust on their surface; they were then sorted to identify and remove broken or scratched fruits. The fruits were flooded with ionized water for $6 \mathrm{~h}$ and divided into seeds, peel, and pulp. The seeds were manually separated from the peel and pulp, and the seeds and peel were then sun dried for 4 days. Drying was completed in an oven for $24 \mathrm{~h}$ at $40{ }^{\circ} \mathrm{C}$. Dried samples were ground into a powder using a blender $(25000 \mathrm{rpm}$, type WK 1000A. Qing Zhou Jing Cheng Machinery Co., LTD, Shandong, China) and then passed through a 60-mesh sieve to produce a fine powder. The powder was sealed in plastic bags and stored in a refrigerator at $4{ }^{\circ} \mathrm{C}$, and the pulp was collected in plastic bags and stored at $-20{ }^{\circ} \mathrm{C}$ in a refrigerator until use. Analytical reagents and HPLC-grade solvents were obtained from Sinopharm Chemical Reagent Co. Ltd., Shanghai, China.

\section{Chemical composition}

The moisture, fat, fiber, and ash contents were determined using standard AOAC International methods 925.09, 932.06, 985.2912, and 923.03, respectively [4]. The ash content was estimated by weighing $2 \mathrm{~g}$ of the sample in a porcelain crucible and burning at $600{ }^{\circ} \mathrm{C}$ for $6 \mathrm{~h}$ in an ashing muffle furnace until a white ash was obtained. For crude fiber, $2 \mathrm{~g}$ of moisture-free sample was weighed, extracted by ether, and digested with dilute $\mathrm{H}_{2} \mathrm{SO}_{4}$ and then with $\mathrm{KOH}$ solution. Fat was determined by petroleum ether in a soxhlet apparatus (SZC-101 Fat Meter, Xian Jian Instruments Co., Ltd, Shanghai, China) for 5 h. Crude protein was determined using a nitrogen analyzer (DK-3400, FOSS, Hillerød, Denmark), and calculated by multiplying the evaluated total nitrogen by a standard factor of 6.25. The total carbohydrate content was calculated as the difference (i.e., the sum of the moisture, fat, protein, and ash contents was subtracted from 100).

\section{Mineral determination}

Minerals in the sample were determined by the dry-ashing method [5].One gram of sample was acid-digested with an acid mixture $\left(\mathrm{HNO}_{3}: \mathrm{HClO}_{4}\right.$, $5: 1, \mathrm{v} / \mathrm{v})$ in a digestion chamber until a white residue was obtained. The digested samples were dissolved in distilled water and filtered through a Whatman No. 42 filter paper as reported by [6]. The calcium content was estimated by a titrimetric method. The iron content was estimated using a UV-visible spectrophotometer (model UV-160A, Shimadzu, Shanghai, China) at $480 \mathrm{~nm}$ [18], with the blue color that developed measured by the same spectrophotometer at $650 \mathrm{~nm}$. Other minerals were determined by atomic absorption spectroscopy using an instrument (AA 6701F, Shimadzu) equipped with hollow cathode lamps.

\section{Amino acid composition}

Amino acids were determined according to the modified AOAC method 982.30 a [4]. One gram of dried sample was hydrolyzed with $8 \mathrm{ml}$ of $6 \mathrm{M}$ $\mathrm{HCl}$ at $110^{\circ} \mathrm{C}$ for $24 \mathrm{~h}$ under a vacuum. After cooling, the hydrolyzed sample was washed with distilled water, filtered through a Whatman No 40 filter paper, and centrifuged at 10,000 rpm for 10 
min. The supernatant was collected and vacuum dried at $60^{\circ} \mathrm{C}$ using a rotary evaporator; the dried residue was dissolved in $0.02 \mathrm{M} \mathrm{HCl}$. A 50$\mu \mathrm{L}$ sub-sample was injected into an amino acid analyzer (Model 835-50, Hitachi, Tokyo, Japan) equipped with a $162.6 \times 150-\mathrm{mm}$ ion exchange column coated with resin 2619 at $53^{\circ} \mathrm{C}$.

\section{Gas chromatography-mass spectrometry (GC/MS)}

GC/MS was used with a SPAM fiber to separate the volatile compounds on a CP-Sil-8CB (Varian, Walnut Creek, CA, USA), fused silica capillary column (30 m length, $0.25 \mathrm{~mm}$, i.d., and $0.25 \mu \mathrm{m}$ film thickness) in a gas chromatograph (model 3800, Varian, Palo Alto, CA, USA). The split injector was maintained at $220^{\circ} \mathrm{C}$, and the flame ionization detector (FID) was maintained at 250 ${ }^{\circ} \mathrm{C}$; volatile compounds were separated with a capillary column DB WAX $(30 \times 0.25 \mu \mathrm{m}, \mathrm{J} \& \mathrm{~W}$ Scientific, Folsom, CA, USA). The separation was performed as follows: the oven temperature was set at $40^{\circ} \mathrm{C}$, held for $3 \mathrm{~min}$, ramped to 100 ${ }^{\circ} \mathrm{C}$ at a rate of $6^{\circ} \mathrm{C} / \mathrm{min}$, and then ramped to 230 ${ }^{\circ} \mathrm{C}$ at $10^{\circ} \mathrm{C} / \mathrm{min}$. The constant column flow was $0.9 \mathrm{ml} / \mathrm{min}$. Mass spectra were obtained in the Electron Impact $(\mathrm{El}+)$ mode with an energy voltage of $70 \mathrm{eV}$. The mass range was 33 to 450 $\mathrm{m} / \mathrm{z}$. The identification of volatile compounds was conducted by matching the compounds with the mass spectra of standard compounds found in the wily $130 \mathrm{~K}$ and National Institute of Standards and Technology (NIST) 98 libraries of MS spectra based on their retention indices.

\section{Evaluation of physical characteristics}

\section{Color parameters}

A Hunter Lab digital colorimeter (TC-PIIG system, Beijing Optical Instrument Co. Ltd., Beijing, China) was used to measure the color of selected Grewia tenax fruit samples, and the color scale $L^{*} a^{*} b^{*}$ values were recorded. A plastic bag containing the same quantity of samples was placed at the light port $(50 \mathrm{~mm}$ in diameter). The values were read directly by the hunter lab digital colorimeter. We investigated the following parameters using a modified version of the method of [7]: lightness $\left(\mathrm{L}^{*}\right)$, coordinate $\mathrm{red} / \mathrm{green}\left(\mathrm{a}^{*}\right)$, and coordinate yellow/blue $\left(b^{\star}\right)$.

\section{Bulk density (BD)}

The BD of the samples was determined according to a modified version of a method previously suggested by [8]. Samples were gently placed in a $15-\mathrm{mL}$ graduated cylinder. The bottom of the cylinder was gently tapped on a laboratory bench several times until there was no further diminution of the sample level after filling the 15-mL mark. The BD was calculated as the weight of sample per unit volume of sample $(\mathrm{g} / \mathrm{mL})$.

\section{Determination of functional properties}

\section{Water and oil absorption (WAC and OAC) capacities}

The WAC and OAC of samples were determined. Samples $(1 \mathrm{~g})$ were dispersed in $10 \mathrm{ml}$ of distilled water and placed in pre-weighed centrifuge tubes. The dispersions were stirred occasionally, held for $5 \mathrm{~min}$, and then subjected to centrifugation for $20 \mathrm{~min}$ at $500 \mathrm{rpm}$. Supernatant was poured in the graduated cylinder for the determination of oil absorption capacity, and the same method was used for WAC [9].

\section{Foaming capacity (FC)}

FC was investigated according to a slightly modified version of the method described by [10]. Two grams of each sample were mixed with 100 $\mathrm{mL}$ of distilled water. This experiment was performed at room temperature. The solution was whipped with a high-speed homogenizer for 5 min. Foaming capacity was expressed as foam expansion immediately after whipping. The solution was then poured into a 250-mL graduated cylinder. The total sample volume was taken at $30 \mathrm{~s}$ for FC and calculated as in Eq. 1.

$$
\mathrm{FC}(\%)=\{(\mathrm{Va}-\mathrm{Vb}) / \mathrm{Vb}\} 100 .
$$

where $\mathrm{Va}$ and $\mathrm{Vb}$ are the volumes before and after whipping, respectively.

\section{Statistical analysis}

The data were analyzed in terms of means \pm standard deviations $( \pm S D)(n=3)$, and statistical analysis was performed using IBM SPSS Statistics for Windows version 19.0 (SPSS Inc., Chicago, IL, USA). A one-way analysis of variance (ANOVA) was used to determine significant differences between means, and Duncan's test was used to perform multiple comparisons between means. The significance level was defined as $p<0.05$.

\section{RESULTS}

\section{Chemical composition analysis}

The chemical composition of Grewia tenax fruit (seeds, peel, and pulp) is shown in Table 1.

Trop J Pharm Res, December 2015; 14(12): 2249 
Table 1: Chemical composition of seeds, peel, and pulp of Grewia tenax fruits (\%)

\begin{tabular}{|c|c|c|c|}
\hline \multirow[t]{2}{*}{ Content } & \multicolumn{3}{|c|}{ Composition (\%) } \\
\hline & Seed & Peel & Pulp* \\
\hline Moisture & $5.11 \pm 0.06^{c}$ & $6.23 \pm 0.08^{b}$ & $86.52 \pm 0.02^{a}$ \\
\hline Crude fiber & $13.42 \pm 0.80^{\mathrm{D}}$ & $15.33 \pm 0.04^{a}$ & $8.13 \pm 0.60^{c}$ \\
\hline Ash & $4.0 \pm 0.05^{a}$ & $4.0 \pm 0.02^{a}$ & $1.0 \pm 0.03^{\mathrm{b}}$ \\
\hline Crude protein & $7.21 \pm 0.33^{\mathrm{a}}$ & $2.12 \pm 0.03^{c}$ & $3.58 \pm 0.12^{\mathrm{b}}$ \\
\hline Crude fats & $10.7 \pm 0.09^{\mathrm{a}}$ & $1.7 \pm 0.01^{\mathrm{b}}$ & $0.2 \pm 0.01^{\mathrm{c}}$ \\
\hline Carbohydrate & $59.56 \pm 1.78^{C}$ & $70.74 \pm 0.18^{b}$ & $87.09 \pm 0.76^{a}$ \\
\hline
\end{tabular}

Values are means $\pm S D$ s; values in the same row with different superscript letters differed significantly $(p \leq 0.05)$ using Duncan's least significant test. *on a dry-weight basis

Table 2: Mineral content of seeds, peel, and pulp of Grewia tenax fruits (expressed as mg/100g)

\begin{tabular}{lcccc}
\hline Mineral content & Seeds & & Peel & Pulp \\
\hline Copper $(\mathrm{Cu})$ & $1.35 \pm 0.01 \mathrm{a}$ & & $0.78 \pm 0.003 \mathrm{~b}$ & $0.27 \pm 0.001 \mathrm{c}$ \\
Chromium $(\mathrm{Cr})$ & $0.02 \pm 0.002 \mathrm{a}$ & & $0.02 \pm 0.001 \mathrm{a}$ & $0.01 \pm 0.003 \mathrm{~b}$ \\
Lead $(\mathrm{Pb})$ & $0.01 \pm 0.005 \mathrm{~b}$ & & $0.01 \pm 0.001 \mathrm{a}$ & $0.015 \pm 0.002 \mathrm{a}$ \\
Manganese $(\mathrm{Mn})$ & $1.70 \pm 0.04 \mathrm{a}$ & $0.62 \pm 0.03 \mathrm{~b}$ & $0.28 \pm 0.03 \mathrm{c}$ \\
Potassium $(\mathrm{K})$ & $400 \pm 0.11 \mathrm{~b}$ & $502.5 \pm 0.09 \mathrm{a}$ & $300 \pm 0.11 \mathrm{c}$ \\
Sodium $(\mathrm{Na})$ & $5.82 \pm 0.03 \mathrm{c}$ & $19.32 \pm 0.02 \mathrm{a}$ & $11.57 \pm 0.13 \mathrm{~b}$ \\
Iron $(\mathrm{Fe})$ & $3.65 \pm 0.07 \mathrm{~b}$ & $3.25 \pm 0.05 \mathrm{~b}$ & $4.00 \pm 0.11 \mathrm{a}$ \\
\hline
\end{tabular}

Values are means \pm SDs; values in the same row with different superscript letters differed significantly $(p \leq 0.05)$ using Duncan's least significant test

Based on dry weights, the moisture distribution of Grewia tenax fruits was as follows: seeds, 5.11 $\%$; peel, $6.23 \%$; and pulp, $86.52 \%$. The crude protein content of seeds, peel, and pulp were $7.21,2.12$, and $3.58 \%$ respectively. The seeds contained more fats $(10.7 \%)$ than did the peel and pulp (1.7 and $0.2 \%$, respectively). The carbohydrate content was $59.56 \%$ for seeds, $70.74 \%$ for peel, and $87.09 \%$ for pulp.

\section{Mineral composition}

The mineral contents of the seeds, peel, and pulp of Grewia tenax fruits are shown in Table 2. The highest values of $\mathrm{K}$ and $\mathrm{Na}$ were found in the peel, and these differed significantly $(p \leq$ 0.05 ) compared with the values for the seeds and pulp. The levels of $\mathrm{Cu}$ and $\mathrm{Mn}$ in the seeds differed significantly $(p \leq 0.05)$ compared with those of the peel and pulp, whereas $\mathrm{Cr}$ and $\mathrm{Fe}$ were present at low levels in all samples.

\section{Amino acid composition}

The concentration of amino acids in the samples is shown in Table 3. A total of 18 amino acids were present in the different parts of Grewia tenax fruits. The pulp contained the essential amino acids, histidine, thereonine, valine, isoleucine, and lysine at concentrations of 4.29 , $6.43,9.70,9.54$, and $6.46 \mathrm{~g} / 100 \mathrm{~g}$, respectively.

\section{Volatile compounds}

The volatile components of the seeds, peel, and pulp of Grewia tenax fruits are summarized in Table 4. More than 82 volatile compounds were identified in the pulp, whereas 43 and 33 components were found in the peel and seeds, respectively. These components were found in different percentages in various parts of the fruits. The most common volatile component was 5, 9-undecadien-2-ol, 6, 10-dimethyl, with a content ranging from $1.01 \%$ in the pulp to 22.18 $\%$ in the peel, whereas it was not present in the seeds. The ethanol content was $16.68,3.08$ and $2.97 \%$ in the pulp, peel, and seeds, respectively. Total concentrations of the volatile components of seeds, peel, and pulp of Grewia tenax fruits were $42.1,97.9$ and $71.4 \%$, respectively.

\section{Color}

The results obtained for color measurements by hunter color values $\left(L^{*}, a^{*}, b^{*}\right)$ for different samples are presented in Table 5 . The lightness $\left(L^{*}\right)$ values of seeds and peel $(p>0.05)$ were 68.38 and 68.81 , respectively, whereas pulp had a lower value, 45.84 . In terms of the red-green coordinate, the redness $\left(a^{*}\right)$ value for pulp was high, 21.42, whereas those for peel and seeds were 10.49 and 5.06, respectively $(p>0.05)$. 
Table 3: Amino acid concentrations in the seeds, peel, and pulp of Grewia tenax fruits $(\mathrm{g} / 100 \mathrm{~g})$ and the Daily Recommended Allowance (DRA) for children and adults according to the Food and Agriculture Organization of the United Nations / World Health Organization / United Nations University (FAOMHO/UNU)

\begin{tabular}{|c|c|c|c|c|c|}
\hline \multirow{3}{*}{$\begin{array}{c}\text { Essential Amino } \\
\text { Acids } \\
\text { (EAA) }\end{array}$} & \multirow{2}{*}{\multicolumn{3}{|c|}{$\begin{array}{c}\text { IAA } \\
g / 100 g\end{array}$}} & \multicolumn{2}{|c|}{ FAO/WHO/UNU ${ }^{a}$} \\
\hline & & & & \multirow{2}{*}{ Child } & \multirow{2}{*}{ Adult } \\
\hline & Seeds & Peel & Pulp & & \\
\hline Histidine & 2.03 & 8.56 & 4.29 & 1.90 & 1.60 \\
\hline Thereonine & 2.72 & 1.56 & 6.43 & 3.40 & 0.90 \\
\hline Arginine & 9.12 & 4.15 & 3.59 & - & - \\
\hline Valine & 4.90 & 2.23 & 9.70 & 3.50 & 1.30 \\
\hline Methionine & 1.72 & 9.32 & 1.40 & $2.70^{\mathrm{b}}$ & $1.70^{k}$ \\
\hline Phenylalanine & 4.66 & 2.05 & 1.06 & $6.30^{c}$ & $1.90^{\circ}$ \\
\hline Isoleucine & 3.41 & 1.92 & 9.54 & 2.80 & 1.30 \\
\hline Leucine & 6.04 & 2.66 & 1.20 & 6.60 & 1.90 \\
\hline Lysine & 1.23 & 1.89 & 6.46 & 5.80 & 1.60 \\
\hline Total & 35.83 & 34.34 & 43.67 & 33 & 12.2 \\
\hline \multicolumn{6}{|c|}{ Non-essential amino acids } \\
\hline Tyrosine & 1.29 & 1.01 & 4.93 & & \\
\hline Cysteine & 4.19 & 1.22 & 4.87 & & \\
\hline Aspartic acid & 8.57 & 5.41 & 2.63 & & \\
\hline Glutamic acid & 1.90 & 4.56 & 2.18 & & \\
\hline Serine & 3.20 & 1.67 & 6.46 & & \\
\hline Glycine & 4.95 & 2.90 & 1.01 & & \\
\hline Arginine & 9.12 & 4.15 & 3.59 & & \\
\hline Proline & 4.54 & 1.76 & 1.00 & & \\
\hline Alanine & 3.81 & 2.15 & 1.10 & & \\
\hline \multirow[t]{2}{*}{ Total } & 41.57 & 24.83 & 27.77 & & \\
\hline & \multicolumn{3}{|c|}{ Proportion of different of amino acids ${ }^{a}$} & & \\
\hline Large hydrophobic & 25.27 & 19.34 & 24 & & \\
\hline Polar & 11.4 & 5.46 & 22.69 & & \\
\hline Charged & 22.85 & 24.57 & 19.15 & & \\
\hline \multicolumn{6}{|c|}{$\begin{array}{l}{ }^{a} \text { FAO/WHO/UNU: Daily health requirements for children and adults from observed intakes (FAO, } \\
2007) .{ }^{b} \text { Requirements for methionine }+ \text { cysteine. }{ }^{c} \text { Requirements for phenylalanine }+ \text { tyrosine. IAA: Indispensable } \\
\text { amino acid of Grewia tenax fruits. }{ }^{d} \text { Large hydrophobic (valine, leucine, isoleucine, methionine, proline, and } \\
\text { phenylalanine), polar (serine, thereonine, tyrosine, and cysteine), and charged amino acids (lysine, arginine, } \\
\text { histidine, aspartic acid, and glutamic acid) }\end{array}$} \\
\hline
\end{tabular}

In terms of the yellow-blue coordinates, the yellowness $\left(b^{*}\right)$ values were $28.71,28.60$, and 19.55 for pulp, peel, and seed samples, respectively $(p<0.05)$.

\section{Bulk density (BD)}

The BD values of Grewia tenax (seeds, peel, and pulp) samples, which are shown in Figure 1, were $0.55,0.56$, and $0.94 \mathrm{~g} / \mathrm{ml}$, respectively $(p<$ 0.05).

\section{Water and oil absorption capacities (WAC and $\mathrm{OAC}$ )}

Variations in the WAC and OAC among the different samples are presented in Figure 1. The results indicate that pulp had the highest WAC (3.3 $\mathrm{ml} / \mathrm{g})$, followed by the peel $(2.5 \mathrm{ml} / \mathrm{g})$, whereas the lowest result was observed for seeds $(1.2 \mathrm{ml} / \mathrm{g})$. The OAC of different samples ranged from 1.16 to $3.6 \mathrm{ml} / \mathrm{g}$.

\section{Foaming capacity (FC)}

The FC results indicate that seeds had the highest value (8.62 \%), followed by pulp (6.51 $\%)$, and then peel (5.5\%).

\section{DISCUSSION}

The moisture content of seeds was lower than that reported [2] previously (7.30 \%) for Grewia tenax fruits. Moisture is an important parameter in the storage of flours, with levels greater than $12 \%$ allowing for microbial growth [8]. Table 1 shows that the fiber content of Grewia tenax pulp was lower than that for its peel and seeds. The ash content of pulp was lower than that of peel and seeds. The protein content of seeds was similar to that reported previously $(7.50 \%)$ [2]. The carbohydrate content was higher in the pulp than in the peel and seeds. The levels of potassium were higher than those of the other minerals in all samples (peel, seeds, and pulp). 
Table 4: Volatile compounds and the chromatographic profile of seeds, peel, and pulp of (Grewia tenax) fruit

\begin{tabular}{|c|c|c|c|c|c|c|c|}
\hline \multirow[t]{2}{*}{ No. } & \multirow[t]{2}{*}{ Constituent } & \multicolumn{3}{|l|}{$\mathbf{R T}^{\star}$} & \multicolumn{3}{|c|}{ Relative peak area \% } \\
\hline & & Seeds & Peel & Pulp & Seeds & Peel & Pulp \\
\hline 1. & Acetic acid, ethyl ester & 3.46 & - & 3.45 & 1.71 & - & 0.87 \\
\hline 2. & Ethanol & 4.24 & 4.25 & 4.27 & 2.97 & 3.08 & 16.68 \\
\hline 3. & Propane, 2-(ethenyloxy)- & - & 5.18 & - & - & 1.01 & - \\
\hline 4. & 2-Pentanone & - & 5.18 & 4.96 & - & - & 1.03 \\
\hline 5. & Benzeneacetic acid, 2-tetradecyl ester & 6.26 & - & - & 1.02 & - & - \\
\hline 6. & 2-Butenal & - & 6.27 & - & - & 0.98 & - \\
\hline 7. & Hexanal & 7.28 & 7.28 & 7.26 & - & 6.35 & 1.39 \\
\hline 8. & 2-Propanol, 1-methoxy- & - & 8.46 & 9.01 & - & 4.40 & - \\
\hline 9. & 1-Butanol & - & 8.95 & 9.42 & - & 3.87 & 10.7 \\
\hline 10. & Heptanal, 2-methyl- & - & - & 9.65 & - & - & 1.33 \\
\hline 11. & 1-Butanol, 3-methyl- & 10.49 & 10.50 & 10.76 & 0.53 & 0.52 & 2.33 \\
\hline 12. & Furan, 2-pentyl- & 11.03 & 11.03 & - & 0.59 & 0.50 & - \\
\hline 13. & Heptadecane & 11.35 & 11.35 & - & 1.01 & 0.74 & - \\
\hline 14. & 1-Pentanol & 11.53 & 11.53 & 11.71 & 5.42 & 0.97 & 1.25 \\
\hline 15. & Octanal & 12.40 & 12.40 & 12.20 & - & 0.81 & 0.68 \\
\hline 16. & 2-Butanone, 3-hydroxy- & - & 12.24 & 12.52 & - & 0.96 & - \\
\hline 17. & 2-Penten-1-ol, (Z)- & - & 13.17 & 13.25 & - & 2.16 & 1.29 \\
\hline 18. & 6-Methyl-5-hepten-2-one & 13.51 & 13.51 & 13.44 & 0.58 & 1.27 & 0.71 \\
\hline 19. & 1-Hexanol & 13.90 & 13.90 & 13.94 & 7.24 & 1.79 & 4.68 \\
\hline 20. & Tridecane, 3-methyl- & 14.16 & 14.16 & - & 0.88 & 0.61 & - \\
\hline 21. & Pentadecane & 14.59 & 14.81 & - & - & 3.23 & - \\
\hline 22. & Nonanal & 14.68 & 14.69 & 14.56 & 9.45 & 15.73 & 5.86 \\
\hline 23. & 1-Octen-3-ol & 15.71 & 15.71 & 15.69 & 4.00 & 0.65 & 0.50 \\
\hline 24. & Decanal & 16.51 & 16.51 & 16.43 & 2.80 & 4.72 & 1.09 \\
\hline 25. & Benzaldehyde & 16.87 & - & 16.85 & - & - & 0.59 \\
\hline 26. & 1-Octanol & - & 17.40 & 17.39 & & 0.69 & 1.77 \\
\hline 27. & 2,3-Butanediol, [S- $\left.\left(\mathrm{R}^{*}, \mathrm{R}^{*}\right)\right]-$ & 17.63 & 17.63 & 17.64 & - & 0.59 & 0.63 \\
\hline 28. & Butyrolactone & 18.39 & - & 18.41 & 1.06 & - & - \\
\hline 29. & Silanediol, dimethyl- & - & - & 18.55 & - & - & 2.12 \\
\hline 30. & 1-Nonanol & 18.79 & 18.79 & 18.77 & 1.24 & 1.16 & 2.41 \\
\hline 31. & 2,5-Heptadien-1-ol, (Z,E)- & - & 19.15 & 19.14 & - & 0.78 & 1.42 \\
\hline 32. & 2-Furanmethanol, 5-methyl- & - & - & 19.54 & - & - & 1.43 \\
\hline 33. & 5,9-Undecadien-2-one, 6,10-dimethyl-,(E) & - & 21.15 & 21.12 & - & 1.81 & 2.04 \\
\hline 34. & Benzyl alcohol & - & 21.38 & 21.38 & - & - & 1.99 \\
\hline 35. & Phenol, 2,6-bis(1,1-dimethylethyl)-4-met & 21.76 & - & 21.73 & 0.69 & - & - \\
\hline 36. & Phenylethyl Alcohol & - & 21.78 & 21.78 & - & 0.85 & 3.04 \\
\hline 37. & 5,9-Undecadien-2-ol, 6,10-dimethyl- & - & 22.18 & 22.18 & - & 22.18 & 1.01 \\
\hline 38. & $2(4 \mathrm{H})$-Bezofuranone, $5,6,7,7$ a tetrahydro & - & 26.18 & 26.18 & - & 1.17 & 1.64 \\
\hline 39. & 1,2-Benzenedicarboxylic acid, bis(meth) & 27.97 & 27.98 & 27.97 & 0.91 & 14.36 & 0.92 \\
\hline & Total & & & & 42.1 & 97.9 & 71.4 \\
\hline
\end{tabular}

${ }^{*} R T=$ retention time per minutes; "-" means the content $<0.5 \%$

Table 5: Color parameters of different parts of (Grewia tenax) fruits: seeds, peel, and pulp

\begin{tabular}{lccc}
\hline Parameter & \multicolumn{3}{c}{ Sample } \\
\cline { 2 - 4 } & Seeds & Peel & Pulp \\
\hline $\mathrm{L}^{*}$ & $68.38 \pm 0.05^{\mathrm{a}}$ & $68.51 \pm 0.39^{\mathrm{a}}$ & $45.84 \pm 0.03^{\mathrm{b}}$ \\
$\mathrm{a}^{*}$ & $5.06 \pm 0.04^{\mathrm{c}}$ & $10.49 \pm 0.10^{\mathrm{D}}$ & $21.42 \pm 0.06^{\mathrm{a}}$ \\
$\mathrm{b}^{*}$ & $19.55 \pm 0.19^{\mathrm{b}}$ & $28.60 \pm 0.05^{\mathrm{a}}$ & $28.71 \pm 0.03^{\mathrm{a}}$
\end{tabular}

Values are means ( $\pm S D s), n=3$. Mean values in the same row with different letters differed significantly ( $p$ $<0.05)$. $L^{*} a^{*} b^{*}$ is an international standard for color measurements $L^{*}$ is the lightness component, which ranges from 0 to 100 , and the parameters $a^{*}$ (from green to red) and $b^{*}$ (from blue to yellow) are the two chromatic components, which range from 120 to 120 


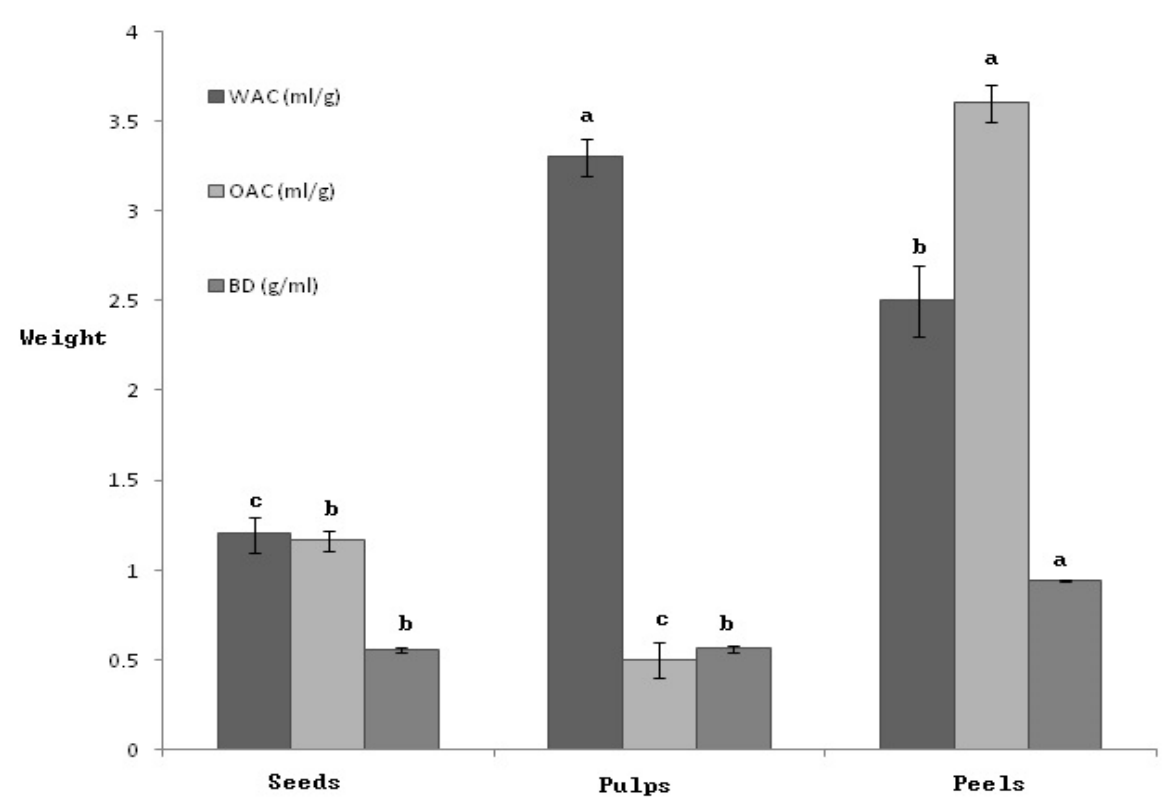

Figure 1: Water absorption capacity (WAC), oil absorption capacity (OAC), and bulk density (BD) of different parts of Grewia tenax fruits: seeds, pulp, and peel. Means \pm SD $(n=3)$. Mean values with different letters differed significantly $(p<0.05)$

The results show that Grewia tenax contains many important minerals that can be used in cereal and cereal products, especially flour for baked good, to improve their nutritional properties. Mineral elements are considered to be essential substances for the healthy functioning of an organism [14,15].

The quantities of essential amino acids was compared with those found by a previous report [12] in terms of the daily amounts currently recommended for an adult human (standard protein). The peel and pulp contained higher levels of some amino acids than the requirements for adult humans issued by the Food and Agriculture Organization of the United Nations/World Health Organization/United Nations University (FAO/WHO/UNU), which indicates that they could be used in some medical applications as a good source of amino acids. Different parts of Grewia tenax fruits contained higher amounts of charged amino acids than of large hydrophobic and polar amino acids.

A small subset of these compounds can be sensed by animals and humans, with the volatile profiles being the defining elements of the distinct flavors of individual foods. The volatiles responsible for flavor are derived from an array of nutrients, including amino acids, fatty acids, and carotenoids. The predominance of volatiles derived from essential nutrients and healthpromoting compounds suggests that these volatiles provide important information about the nutritional composition of foods. However,
Grewia tenax fruits can be considered to be a good source of volatile compounds and can be used as an additive to many foods or beverages to provide a better taste and flavor.

Color is one of the most important quality parameters in food products, and color changes caused by dietary fibers limit their potential application in food [16]. The high $L^{*}$ values of seeds, peel, and pulp, together with their high water absorption capacity (WAC) values, indicate a likely improvement in the lightness of food products to which they are added. BD is a reflection of the load that a sample can carry if it is allowed to rest directly on another, and the BD of flour can be used to determine its packaging requirements [8].

The WAC of pulp was higher than those of the other samples, which suggests that it could be useful in the industrial production of food and food products. The OAC values of the different samples are presented in Figure 1. The OAC is of great importance from an industrial perspective, because it reflects the emulsifying capacity.

FC is one of the most important quality parameters in food products and food. In this study, the seeds of Grewia tenax had the highest FC.

\section{CONCLUSION}

The findings of this study indicate that the chemical composition, functional properties, and 
volatile compounds of the seeds, peel, and pulp of Grewia tenax differed significantly. It was found that the pulp had highest levels of essential amino acids (EAA), which is the most important quality parameter in food products. Furthermore, the use of Grewia tenax fruits to meet human nutritional needs to be extensively promoted to ensure both good health and nutrition, especially to poor and low-resource communities in developing countries.

\section{ACKNOWLEDGEMENT}

The authors gratefully acknowledge the financial support provided by the National Key of Technology R\&D Program in the 12th Five-Year plan of China. The authors are also indebted to the staff at the food enzymology laboratory at the School of Food Science and Technology, Jiangnan University for their technical assistance.

\section{REFERENCES}

1. FAO. Traditional Food Plants: A Resource Book for Promoting the Exploitation Consumption of Food Plant in Arid, Semi-arid and Sub-humid Lands of Eastern Africa. Rome: FAO Food and Nutrition 1988; paper 42.

2. Abdualrahman MAY, Ali AO, Suliman AM. Nutritional Evaluation of Guddaim Fruits (Grewia tenax) and its Utilization in Ice Cream Production. J. Sc. Tech 2011; 12: 03 .

3. Aboagarib EAA, Yang R, Hua X, Siddeeg A. Chemical Compositions, Nutritional Properties and Volatile Compounds of Guddaim (Grewia Tenax.Forssk) Fiori Fruits.J Food Nutr Res 2014; 2: 187-192.

4. AOAC. Official methods of analysis of the AOAC, 15th edn. Methods 932.06, 925.09, 985.29, 923.03. Association of Official Analytical Chemists Arlington, VA, USA 1990.

5. Chapman $H$, Pratt F. Determination of minerals by titration method. Methods of Analysis for Soils, Plants and Water, 2nd edn Oakland, CA: Agriculture Division, California University 1982: 169-170.

6. Al-Numair KS, Ahmed SEB, Al-Assaf AH, Alamri MS. Hydrochloric acid extractable minerals and phytate and polyphenols contents of sprouted faba and white bean cultivars. Food Chem 2009; 113: 997-1002.

7. Sánchez-Zapata E, Fuentes-Zaragoza El, FernándezLópez J, Sendra E, Sayas E, Navarro $C$, et al.
Preparation of dietary fiber powder from tiger nut (Cyperus esculentus) milk ("Horchata") byproducts and its physicochemical properties. J Agric Food Chem 2009; 57: 7719-7725.

8. Kaur $M$, Kaushal $P$, Sandhu KS. Studies on physicochemical and pasting properties of Taro (Colocasia esculenta L.) flour in comparison with a cereal, tuber and legume flour. J Food Sci Technol 2013; 50: 94-100.

9. Onwuka G. Food analysis and instrumentation: theory and practice. Food Sci J 2005; 8: 3-35.

10. Ogunwolu SO, Henshaw FO, Mock H-P, Santros A, Awonorin SO. Functional properties of protein concentrates and isolates produced from cashew (Anacardium occidentale L.) Nut. Food Chem 2009; 115: 852-858.

11. Kim M-Y, Lee S-J, Ahn J-K, Kim E-H, Kim M-J, Kim S-L, et al. Comparison of free amino acid, carbohydrates concentrations in Korean edible and medicinal mushrooms. Food Chem 2009; 113: 386-393.

12. FAO. Protein and amino acid requirements in human nutrition. Report of a joint WHO/FAO/UNU, expert consultation. Geneva, Switzerland. WHO technical 2007; 935.

13. Singh N, Kaur M, Sandhu KS, Guraya HS. Physicochemical, thermal, morphological and pasting properties of starches from some Indian black gram (Phaseolus mungo L.) cultivars. Starch Stärke 2004; 56: 535-544.

14. de Silva DM, Askwith CC, Kaplan J. Molecular mechanisms of iron uptake in eukaryotes. Physiol Rev 1996; 76: 31-47.

15. Richardson DR, Ponka P. The molecular mechanisms of the metabolism and transport of iron in normal and neoplastic cells. BBA-Rev Biomembrans 1997; 1331: $1-40$.

16. Viuda-Martos $M$, Ruiz-Navajas $Y$, Martin-Sánchez $A$, Sánchez-Zapata E, Fernández-López J, Sendra E, et al. Chemical, physico-chemical and functional properties of pomegranate (Punica granatum L.) bagasses powder co-product. J Food Eng 2012; 110: 220-224.

17. Kaur M, Singh N, Sandhu KS. Preparation and characterization of protein isolates from different lentil (Lens culinatis) cultivars. J Food Sci Tech Mys 2007; 44:327-329.

18. AOAC. Official Methods of Analysis of the AOAC international, 16th ed. Method 970.12. Association of Official Analytical Chemists International. Washington, DC, USA 1995. 